\title{
Article \\ Effect of the Pyrolysis Process Applied to Waste Branches Biomass from Fruit Trees on the Calorific Value of the Biochar and Dust Explosivity
}

\author{
Bogdan Saletnik*(D), Marcin Bajcar, Aneta Saletnik, Grzegorz Zaguła (D) and Czesław Puchalski
}

Citation: Saletnik, B.; Bajcar, M.; Saletnik, A.; Zaguła, G.; Puchalski, C. Effect of the Pyrolysis Process Applied to Waste Branches Biomass from Fruit Trees on the Calorific Value of the Biochar and Dust Explosivity. Energies 2021, 14, 4898. https://doi.org/10.3390/en14164898

Academic Editor: Attilio Converti

Received: 22 July 2021

Accepted: 9 August 2021

Published: 11 August 2021

Publisher's Note: MDPI stays neutral with regard to jurisdictional claims in published maps and institutional affiliations.

Copyright: (c) 2021 by the authors. Licensee MDPI, Basel, Switzerland. This article is an open access article distributed under the terms and conditions of the Creative Commons Attribution (CC BY) license (https:/ / creativecommons.org/licenses/by/ $4.0 /)$.
Department of Bioenergetics, Food Analysis and Microbiology, Institute of Food Technology and Nutrition, College of Natural Science, Rzeszow University, Ćwiklińskiej 2D, 35-601 Rzeszow, Poland; mbajcar@ur.edu.pl (M.B.); a.saletnik@ur.edu.pl (A.S.); g_zagula@ur.edu.pl (G.Z.); cpuchal@ur.edu.pl (C.P.)

* Correspondence: bogdan.saletnik@urz.pl

Abstract: The article discusses the findings related to the calorific value as well as the explosion and combustion parameters of dust from the raw biomass of fruit trees, i.e., apple, cherry, and pear branches, and from biochars produced using this type of biomass during pyrolysis processes conducted under various conditions. The plant biomass was thermally processed at 400,450 , or $500{ }^{\circ} \mathrm{C}$ for a duration of 5,10 , or $15 \mathrm{~min}$. The study aimed to identify the calorific value of the biomass obtained from waste produced in orchards and to estimate the explosion hazard during the processing of such materials and during the storage of the resulting solid fuels. Tests were conducted to assess the total contents of carbon, ash, nitrogen, hydrogen, and volatile substances as well as the calorific value. The findings show a significant effect of the thermal transformation of fruit tree branches on the calorific value of the biochars that were produced. It was found that the mean calorific value of all of the biochars was increased by $62.24 \%$ compared to the non-processed biomass. More specifically, the mean calorific values of the biochars produced from apple, cherry, and pear branches amounted to $27.90,28.75$, and $26.84 \mathrm{MJ} \mathrm{kg}^{-1}$, respectively. The maximum explosion pressure $P_{\max }$ measured for the dust from the biomass and for the biochars was in the range 7.56-7.8 and 7.95-11.72 bar, respectively. The maximum rate of pressure rose over time $(d p / d t)_{\max }$ in the case of the dust from the biomass, which was in the range of $274.77-284.97$ bar s$^{-1}$, and the dust from biochar amounted to 282.05-353.41 bar s $^{-1}$. The explosion index $K_{s t}$ max measured for non-processed biomass and biochars was found to range from 74.46 to 77.23 and from 76.447 to 95.77 bar s $^{-1}$, respectively. It was also shown that a change in the temperature and duration of the pyrolysis process affected the quality of the biochars that were obtained. The findings show that pyrolysis, as a method of plant biomass processing, positively affects the calorific value of the products and does not lead to an increased risk of explosion during the treatment and storage of such materials. It is necessary, however, to continue research on biomass processing in order to develop practices that adequately ensure safety during the production of novel fuels.

Keywords: fruit tree branches; pyrolysis; calorific value; explosibility; dust

\section{Introduction}

The steadily increasing demand for energy that has been observed worldwide is correlated with economic growth and the decreasing availability of conventional non-renewable natural resources. The search for and improvement of alternative energy sources is of key importance to the energy sector, environmental protection, and overall sustainable development. Fossil fuels, such as coal, lignite, natural gas, and oil, are the main resources utilised in energy production in Poland and globally. With the rapidly increasing population, the problem of energy production today is becoming more and more serious. The growing demand for energy, as a consequence, leads to higher greenhouse gas emissions resulting from the combustion of conventional fuels. Furthermore, the continuous depletion of 
natural resources is one of the reasons why it is necessary to investigate novel sources that could be used in the production of energy. The utilisation of plant biomass as a fuel in energy production may, to a degree, provide a solution to this problem. However, biomass as an energy carrier presents certain drawbacks, such as the low density of the raw material, which makes transport and storage difficult, as well as the varied moisture level, which poses difficulty in the processes of preparation and utilisation for energy-related purposes. Biochar that has been produced in the process of pyrolysis may be an answer to these problems. Hence, it may potentially also be one of the solutions to tackle climate change and to ensure sustainable energy production as well as the management of crop residues [1].

Pyrolysis involves thermochemical conversion taking place in an anaerobic atmosphere. This is a complex process whereby chemical compounds decompose into molecules of smaller size, which is induced by a high temperature supplied from an external source. Most reactions occurring during the process are endothermic, which means they absorb heat from the environment [2]. The pyrolysis process may be applied to various materials of organic origin. The process of pyrolysis is affected by numerous parameters that determine the type and quality of its products. Depending on the conditions of the process, it is possible to obtain biochar and bio-oil as well as pyrolytic gas with specific capacities. These conditions need to be controlled to achieve the desired result, e.g., to produce a greater quantity of biochar. Many factors affect the properties of the pyrolysis products, with the type of biomass used being of key importance. Furthermore, the composition and quantity of the products are directly affected by the type of pyrolysis reactor, the way in which the biomass is heated, the temperature, and the temperature increase over time as well as the residence time, the pressure, the way the material is prepared, the flow rate of the medium, and the catalyst $[3,4]$.

Characterization of the fuel properties is essential for the design and operation of the associated biomass combustion facilities. Calorific value is one of the most important thermal properties that is often required in thermodynamic calculations. The heating value of a fuel can be reported in terms of a lower (LHV) or higher (HHV) value. The higher heating value (HHV) indicates the total amount of heat released by the complete combustion of a specified amount of fuel. This parameter is one of the most critical fuel properties and can be used for the optimization of biomass fueled thermal energy [5-7].

Production of biochar from waste biomass, including residues from orchards, may be an answer to the increasing demand for energy and to problems related to the management of biodegradable waste [8]. This method of waste utilisation may be important for environmental protection. The product, made from waste wood biomass through the pyrolysis process, may be a valuable renewable fuel to be used in the energy sector. It can be burnt in power stations or in cogeneration plants. Biochar can also be used for other interesting energy-related purposes, such as electrocatalysis, fuel cells, supercapacitors, and accumulators [9,10].

During processing, plant biomass is commonly refined into smaller fractions and as a result of which, a significant amount of dust is produced, adversely affecting the facility and the equipment. This phenomenon is associated with a considerable risk of explosion or self-ignition. Since many energy technologies are linked with explosion hazards, in recent years, various procedures have been developed to provide protection against such risks. Nevertheless, it appears that further research in this area is needed. Developments in large power installations, an increasing number of small installations as well as novel fuels introduced in the prosumer energy sector suggest that it is necessary to constantly review the procedures and continue the related research. In the literature on the subject, there is no complete information on the explosion parameters of biochar dusts. Additionally, explosion hazards are known in many energy technologies and a variety of procedures to provide protection against explosions have been developed over the years. However, protection plans have been developed for large installations, while recent years have seen a noticeable increase in the number of micro-installations in addition to the new fuels being 
introduced in the prosumer energy sector. Given this, there is a continued need for related research [11-14].

Dust explosions frequently occur during the processing of materials involving the use of milling and crushing machines as well as the handling and storage of equipment. These operations are widely used in industrial plants and will continue to be used in emerging industries. Consequently, the likelihood of a dust explosion remains an ongoing hazard [15-17]. In facilities where fine dust spreads in the air, an explosion may occur immediately, depending on the source of ignition, once certain conditions are met, i.e., when the minimum explosive concentration is achieved. The types of dust causing explosions may come from wood, paper products, food products, and metal as well as metal products and are associated with the power industry, coal mining, and textile production [18,19]. Dust self-ignition may be induced by a number of factors. The conditions and factors that are necessary for a dust explosion to occur are illustrated by the so-called "explosion pentagon", i.e., fuel in the form of dust particles, oxidant, an ignition source, the mixing of the fuel and oxidant as well as confinement. In a confined space, sufficient pressure is maintained so that a primary dust explosion may occur. A secondary dust explosion leads to uncontrolled explosions occurring after the blast wave from a primary explosion entrains a layer of dust and is propagated [20-22]. Risk factors potentially leading to a dust explosion include contact of the dust with hot materials as well as defective operation or incorrect use of equipment for the processing of materials. Similarly, hot gases produced during biomass processing present a serious hazard [23]. A significant risk of a potential dust explosion is also associated with electrostatic discharges occurring during the processes of milling, shredding, and grinding applied to lignocellulosic materials [24,25].

In view of the high potential of plant biomass, including waste biomass, for energy production and given the various methods of biomass conversion, it seems necessary to continue research aimed at developing appropriate practices for the production and storage of fuels from various materials. The current study was designed to identify the calorific value of the biomass obtained from waste produced in orchards and to estimate the explosion hazard during the processing of such materials into solid fuels. An assessment of the relationship between the characteristics of the plant biomass pyrolysis process and selected properties of the biochar produced was conducted, taking orchard waste into account.

\section{Materials and Methods}

\subsection{Object of the Research}

Branches of apple, cherry, and pear trees were used in this research. Samples were supplied by an owner of a plantation located in the town of Ropczyce, Podkarpackie Region, Poland. The material intended for the study was brought to an air-dry state and was then subjected to grinding.

\subsection{Pyrolysis Process}

The pyrolysis process was conducted in a LECO TGA 701 stationary bed reactor LECO TGA 701 (Leco, St. Joseph, MI, USA). Examination of the physicochemical properties and pyrolysis tests using a thermobalance were conducted on feedstock with a grain size below $10 \mathrm{~mm}$. Samples of apple, cherry, and pear branches were subjected to a pyrolysis process at 400,450 , and $500{ }^{\circ} \mathrm{C}$ for a duration of 5, 10, and $15 \mathrm{~min}$ in a nitrogen atmosphere with $99.99 \%$ purity and a gas flow (nitrogen) rate of $10 \mathrm{~L} / \mathrm{min}$ and with temperature increases of $30{ }^{\circ} \mathrm{C} / \mathrm{min}$. Subsequently, the products of pyrolysis were sifted using a sieve with mesh size of $1 \mathrm{~mm}$. In order to remove potential contamination, the samples were rinsed a few times with distilled water and were then dried for $12 \mathrm{~h}$ (at a temperature of $80{ }^{\circ} \mathrm{C}$ ).

\subsection{Analysis of Samples}

The basic physicochemical parameters of the materials that were assessed included the total content of carbon, ash, nitrogen, hydrogen, volatile substances, and calorific value. 
The examinations were performed with a LECO TGA 701 thermogravimetric analyser, a LECO TrueSpec CHN elemental composition analyser (LECO, St. Joseph, MI, USA), and a LECO AC 500 isoperibolic calorimeter (LECO, St. Joseph, MI, USA). The method to determine the fixed carbon released on calculations based on the assessment of volatiles according to $\mathrm{FC}=100-(\%$ moisture $+\%$ volatile substances $+\%$ Ash $)$. Explosivity tests were conducted using a KSEP20 device, provided with a KSEP 310 control unit (Kuhner AG, Basel, Switzerland). The device comprises a test chamber with a spherical shape and a volume of $20 \mathrm{dm}^{3}$. Owing to its water jacket, the heat of explosions is dissipated, and thermostatically controlled test temperatures are maintained (Figure 1).

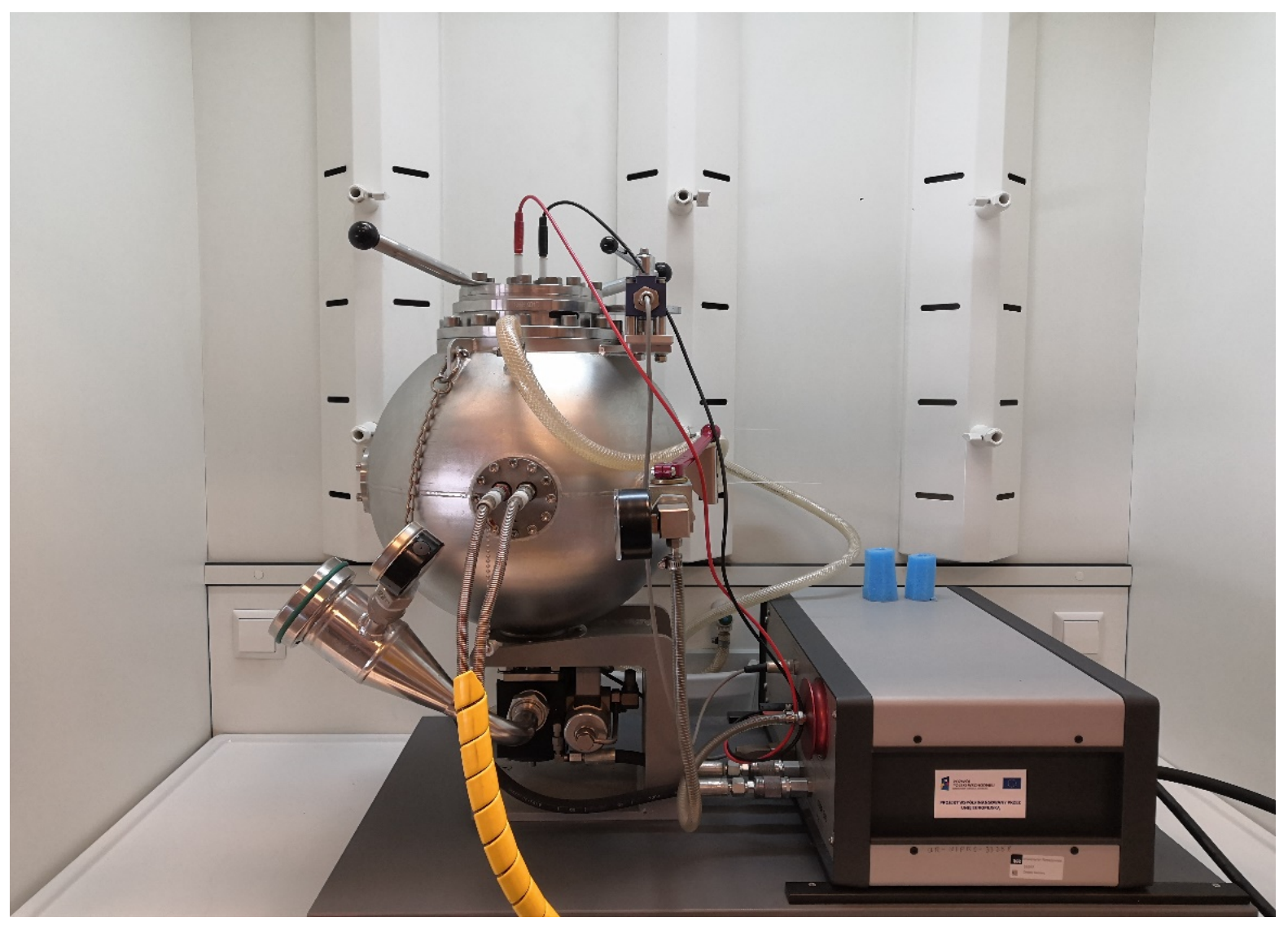

Figure 1. KSEP 310 explosibility analyser.

During the testing procedure, the dust is dispersed under pressure using an outlet valve that opens and closes pneumatically. The source of ignition consists of two chemical ignitors, each with an energy rating of $5 \mathrm{~kJ}$, located centrally in the sphere. The changing process parameters are registered by means of Kistler piezoelectric pressure sensors. The measurements identify the maximum explosion pressure $\mathrm{P}_{\max }$, defined as the highest registered pressure during the explosion of a flammable mixture consisting of a combustible material and air. This parameter is used along with the value of the maximum rate of pressure rise over time $(d p / d t)_{\max }$ to determine the explosion class $K_{s t} \max$. The latter parameter is a measure determining the classification of combustible dust. It was estimated based on the following formula:

$$
K \max =K s t=\sqrt[3]{V\left(\frac{d p}{d t}\right)} \max =0.271\left(\frac{d p}{d t}\right) \max \left[\text { mbars }^{-1}\right]
$$

$K_{s t} \max$-explosion index;

$V$-volume of test chamber;

$(d p / d t)_{\max }$-maximum rate of explosion pressure rise. 
Explosion indices were classified in accordance with the values shown in Table 1, where the St1 Class refers to materials presenting low explosion hazard, the St2 Class refers to materials with a moderate risk of explosion, and the St3 Class refers to materials presenting a high risk of explosion.

Table 1. Classes of dust explosibility [26].

\begin{tabular}{ll}
\hline Explosibility Class & Value $K_{\text {st } \max }\left[\mathrm{bar} \mathrm{s}^{-1}\right]$ \\
\hline St1 & $\leq 200$ \\
St2 & $200-300$ \\
St3 & $>300$ \\
\hline
\end{tabular}

Samples of biomass and biochars were subjected to laboratory analyses using current analytical standards (Table 2).

Table 2. Parameters analysed with research methods.

\begin{tabular}{cc}
\hline Parameter & Research Method \\
\hline Content of carbon, nitrogen and hydrogen & PN-EN 15104:2011 [27] \\
Ash content & PN-EN 13775:2010 [28] \\
Content of volatile substances & PN-EN 15138:2011 [29] \\
Calorific value & PN-EN 13918:2010 [30] \\
Maximum explosion pressure & PN-EN 14034-1 [31] \\
Maximum rate of pressure rise & PN-EN 14034-2 [26] \\
Lower explosion limits & PN-EN 14034-3 [32] \\
Explosion index $K_{s t}$ max & PN-EN 14034-2 [26] \\
\hline
\end{tabular}

\subsection{Names of Tests}

For the purpose of identification, the biomass samples are described with symbols relative to the type of material, temperature, and duration of the pyrolysis process:

A-apple branches;

C-cherry branches;

$\mathrm{P}$ - pear branches;

0 - biomass not subjected to thermal processing;

1 - pyrolysis (temp. $400^{\circ} \mathrm{C} ; 5 \mathrm{~min}$ );

2-pyrolysis (temp. $400^{\circ} \mathrm{C} ; 10 \mathrm{~min}$ );

3-pyrolysis (temp. $400{ }^{\circ} \mathrm{C} ; 15 \mathrm{~min}$ );

4-pyrolysis (temp. $450^{\circ} \mathrm{C} ; 5 \mathrm{~min}$ );

5-pyrolysis (temp. $450^{\circ} \mathrm{C} ; 10 \mathrm{~min}$ );

6-pyrolysis (temp. $450^{\circ} \mathrm{C} ; 15 \mathrm{~min}$ );

7-pyrolysis (temp. $500^{\circ} \mathrm{C} ; 5 \mathrm{~min}$ );

8-pyrolysis (temp. $500^{\circ} \mathrm{C} ; 10 \mathrm{~min}$ );

9-pyrolysis (temp. $500^{\circ} \mathrm{C} ; 15 \mathrm{~min}$ ).

For example, A0-apple branches not subjected to thermal processing; $\mathrm{C} 1$-cherry branches pyrolized at $400{ }^{\circ} \mathrm{C}$ and $5 \mathrm{~min}$; P9-cherry branches pyrolized at $500{ }^{\circ} \mathrm{C}$ and $15 \mathrm{~min}$.

\subsection{Statistical Analysis}

The effects of the experimental factors, reflected by the relevant parameters and the relationships between them, were examined by means of the Duncan test using Analysis of Variance (ANOVA). The Statistica 12 software was used to compute the statistical analyses. A significance threshold of $\leq 0.05$ was set for all analyses. The data were analysed separately for the apple, cherry, and pear branches $[33,34]$. 


\section{Results}

The findings shown in Table 3 reflect per cent contents of total nitrogen, total carbon, hydrogen, ash, volatile substances in the non-processed biomass of apple branches, and biochars produced from this material. Table 2 also presents the calorific value of these materials. Each biochar produced from apple branches differed significantly from the control sample (non-processed biomass), which can be attributed to the contents of the elements. The control sample was found with a $0.47 \%$ nitrogen content, whereas the content of this element in the biochars was in the range of $0.68-1.07 \%$. The highest nitrogen contents, amounting to 1.05 and $1.07 \%$, were identified in the biochars subjected to pyrolysis at $400{ }^{\circ} \mathrm{C}$, with residence time of 5 and $10 \mathrm{~min}$, respectively. The total content of carbon in the non-processed material was $41.42 \%$, whereas the share of this element in the biochars ranged from 67.50 to $73.63 \%$, with the highest values identified in the material processed at $500{ }^{\circ} \mathrm{C}$ for the durations of 10 and $15 \mathrm{~min}$. The fixed carbon content of the tested materials was in the range of $15.22-71.2 \%$. The highest hydrogen content was found in the nonprocessed material (4.95\%), and the lowest $(2.22 \%)$ in the material processed at $500{ }^{\circ} \mathrm{C}$ for a duration of $15 \mathrm{~min}$.

Table 3. Contents of total nitrogen, total carbon, hydrogen, fixed carbon, ash, volatile substances, and calorific value in non-processed biomass of apple branches and in the biochars.

\begin{tabular}{|c|c|c|c|c|c|c|c|}
\hline & Nitrogen & Carbon & Hydrogen & Fixed Carbon & Ash & Volatile Substances & Calorific Value \\
\hline & \multicolumn{6}{|c|}{$\%$} & MJ kg-1 \\
\hline A0 & $0.47^{\mathrm{a}} \pm 0.05$ & $41.42^{\mathrm{a}} \pm 0.20$ & $4.95^{\mathrm{d}} \pm 0.04$ & $15.22^{\mathrm{a}} \pm 0.09$ & $1.71^{\mathrm{a}} \pm 0.07$ & $74.07^{\mathrm{d}} \pm 0.09$ & $17.34^{\mathrm{a}} \pm 0.03$ \\
\hline A1 & $1.07^{\mathrm{f}} \pm 0.35$ & $67.50^{\mathrm{b}} \pm 0.35$ & $3.30^{c} \pm 0.02$ & $65.64^{b c} \pm 0.07$ & $4.96^{b} \pm 0.05$ & $29.4^{c} \pm 0.09$ & $26.11^{b} \pm 0.09$ \\
\hline $\mathrm{A} 2$ & $1.05^{\mathrm{f}} \pm 0.05$ & $70.22^{b c} \pm 0.11$ & $3.24^{c} \pm 0.01$ & $66.5^{b c} \pm 0.06$ & $5.04^{b} \pm 0.03$ & $28.46^{b c} \pm 0.1$ & $27.22^{b} \pm 0.16$ \\
\hline A3 & $0.97^{\mathrm{e}} \pm 0.06$ & $70.24^{b c} \pm 0.24$ & $3.26^{c} \pm 0.02$ & $66.61^{b c} \pm 0.11$ & $5.71^{\mathrm{c}} \pm 0.08$ & $27.68^{b c} \pm 0.12$ & $27.40^{b} \pm 0.09$ \\
\hline $\mathrm{A} 4$ & $0.97^{\mathrm{e}} \pm 0.01$ & $67.88^{b} \pm 0.06$ & $2.82^{b} \pm 0.03$ & $66.12^{b c} \pm 0.12$ & $6.78^{\mathrm{d}} \pm 0.1$ & $27.1^{b c} \pm 0.13$ & $26.64^{b} \pm 0.14$ \\
\hline A5 & $0.98^{\mathrm{e}} \pm 0.01$ & $70.88^{b c} \pm 0.07$ & $2.80^{\mathrm{b}} \pm 0.02$ & $67.48^{b c} \pm 0.06$ & $7.55^{\mathrm{e}} \pm 0.04$ & $24.97^{b c} \pm 0.08$ & $28.36^{b} \pm 0.05$ \\
\hline A6 & $0.89^{\mathrm{d}} \pm 0.03$ & $71.45^{b c} \pm 0.08$ & $2.76^{\mathrm{b}} \pm 0.01$ & $68.74^{b c} \pm 0.08$ & $7.83^{\mathrm{e}} \pm 0.06$ & $23.43^{b c} \pm 0.11$ & $28.73^{b} \pm 0.09$ \\
\hline A7 & $0.68^{c} \pm 0.04$ & $67.85^{b} \pm 0.09$ & $2.48^{\mathrm{a}} \pm 0.01$ & $69.79^{b c} \pm 0.09$ & $6.98^{\mathrm{d}} \pm 0.05$ & $23.23^{b c} \pm 0.12$ & $28.28^{b} \pm 0.09$ \\
\hline A8 & $0.70^{c} \pm 0.01$ & $73.54^{c} \pm 0.07$ & $2.45^{\mathrm{a}} \pm 0.02$ & $71.2^{c} \pm 0.05$ & $7.09^{\mathrm{d}} \pm 0.04$ & $21.71^{b} \pm 0.06$ & $28.89^{b} \pm 0.07$ \\
\hline A9 & $0.60^{\mathrm{b}} \pm 0.01$ & $73.63^{c} \pm 0.19$ & $2.22^{\mathrm{a}} \pm 0.02$ & $71.42^{c} \pm 0.04$ & $7.85^{\mathrm{e}} \pm 0.07$ & $20.73^{a} \pm 0.1$ & $29.49^{b} \pm 0.11$ \\
\hline
\end{tabular}

Differences between average values marked with the same Arabic letters $(\mathrm{a}-\mathrm{d})$ are not statistically significant at the level of $p \leq 0.05$ according to the Duncan test.

The ash content in the control sample was $1.71 \%$, whereas in the biochars, the related value was in the range of $4.96-7.85 \%$. The highest ash contents of $7.55-7.85 \%$, showing a statistically significant increase, were identified in the materials subjected to pyrolysis at $450{ }^{\circ} \mathrm{C}$ for 10 and $15 \mathrm{~min}$ as well as $500{ }^{\circ} \mathrm{C}$ for $15 \mathrm{~min}$. The content of volatile substances in apple branches not subjected to thermal processing was $74.07 \%$, and in the biochars, the value was in the range of $20.73-29.4 \%$. The lowest volatile contents were measured in the case of the material processed at $500{ }^{\circ} \mathrm{C}$ with a residence time of 10 and $15 \mathrm{~min}$.

Statistically significant differences in the calorific value were found between all of the biochars and in the control sample. In the latter, the calorific value was $17.34 \mathrm{MJ} \mathrm{kg}^{-1}$, whereas in the biochars, it was in the range of $26.11-29.49 \mathrm{MJ} \mathrm{kg}^{-1}$. No statistically significant differences relating to this parameter were found between the specific pyrolysis products. Pyrolysis involves the thermo-chemical valorization of biomass into energy. Temperature governs the chemical processes of dehydration, dehydrogenation, depolymerisation, fragmentation, and thermal cracking of facultative products during pyrolysis [35].

Similar to in the above cases, each of the biochars produced from cherry branches differed significantly from the non-processed biomass in the contents of the elements (Table 4). The highest contents of nitrogen, amounting to 1.18 and $1.16 \%$, were identified in the biochars processed at a temperature of $400{ }^{\circ} \mathrm{C}$ for a duration of 5 and $10 \mathrm{~min}$, respectively. As for the contents of total carbon, the highest values were observed in the materials subjected to pyrolysis at $500{ }^{\circ} \mathrm{C}$ for 10 and $15 \mathrm{~min}$. The fixed carbon content of tested materials was in the range of $14.37-72.64 \%$. The highest content of hydrogen was 
measured in the non-processed material (4.66\%), whereas the lowest value $(1.48 \%)$ was found in the case of the material processed at the highest temperature and with the longest residence time.

Table 4. Contents of total nitrogen, total carbon, hydrogen, fixed carbon, ash, volatile substances, and calorific value in non-processed biomass of cherry branches and in the biochars produced.

\begin{tabular}{|c|c|c|c|c|c|c|c|}
\hline & Nitrogen & Carbon & Hydrogen & Fixed Carbon & Ash & Volatile Substances & Calorific Value \\
\hline & & & & $\%$ & & & MJ kg-1 \\
\hline $\mathrm{CO}$ & $0.68^{a} \pm 0.03$ & $44.16^{\mathrm{a}} \pm 0.04$ & $4.66^{\mathrm{d}} \pm 0.02$ & $14.37^{\mathrm{a}} \pm 0.08$ & $1.5^{\mathrm{a}} \pm 0.09$ & $75.13^{d} \pm 0.1$ & $17.96^{\mathrm{a}} \pm 0.04$ \\
\hline $\mathrm{C} 1$ & $1.18^{\mathrm{e}} \pm 0.07$ & $72.30^{b} \pm 0.07$ & $2.89^{c} \pm 0.07$ & $63.84^{b} \pm 0.11$ & $4.3^{b} \pm 0.07$ & $31.86^{c} \pm 0.15$ & $27.71^{b} \pm 0.12$ \\
\hline $\mathrm{C} 2$ & $1.16^{\mathrm{e}} \pm 0.05$ & $75.19^{b c} \pm 0.12$ & $2.78^{c} \pm 0.04$ & $63.46^{b} \pm 0.09$ & $4.69^{b c} \pm 0.08$ & $31.85^{c} \pm 0.11$ & $27.93^{b} \pm 0.07$ \\
\hline C3 & $1.07^{\mathrm{d}} \pm 0.05$ & $76.53^{b c} \pm 0.15$ & $2.62^{\mathrm{c}} \pm 0.02$ & $64.72^{b c} \pm 0.09$ & $5.03^{c} \pm 0.04$ & $30.25^{b c} \pm 0.16$ & $28.09^{b} \pm 0.09$ \\
\hline C4 & $1.07^{\mathrm{d}} \pm 0.01$ & $76.80^{b c} \pm 0.14$ & $2.05^{b} \pm 0.03$ & $66.16^{\mathrm{bc}} \pm 0.07$ & $4.84^{\mathrm{c}} \pm 0.05$ & $29^{b c} \pm 0.11$ & $28.29^{b} \pm 0.11$ \\
\hline C5 & $1.10^{\mathrm{d}} \pm 0.01$ & $77.26^{b c} \pm 0.12$ & $2.04^{b} \pm 0.03$ & $67.36^{b c} \pm 0.08$ & $4.89^{c} \pm 0.03$ & $27.75^{b c} \pm 0.13$ & $28.49^{b} \pm 0.13$ \\
\hline C6 & $1.00^{c} \pm 0.04$ & $79.37^{b c} \pm 0.08$ & $1.87^{\mathrm{ab}} \pm 0.01$ & $69.32^{b c} \pm 0.07$ & $5.4^{\mathrm{d}} \pm 0.07$ & $25.38^{b c} \pm 0.07$ & $28.75^{b} \pm 0.13$ \\
\hline $\mathrm{C} 7$ & $0.80^{\mathrm{b}} \pm 0.03$ & $78.29^{b c} \pm 0.14$ & $1.69^{\mathrm{a}} \pm 0.02$ & $71.13^{b c} \pm 0.06$ & $5.35^{\mathrm{d}} \pm 0.05^{2}$ & $23.52^{b} \pm 0.08$ & $29.61^{b} \pm 0.16$ \\
\hline $\mathrm{C} 8$ & $0.81^{\mathrm{b}} \pm 0.01$ & $80.66^{c} \pm 0.04$ & $1.66^{\mathrm{a}} \pm 0.01$ & $71.83^{b c} \pm 0.06$ & $5.45^{\mathrm{d}} \pm 0.05$ & $22.72^{b} \pm 0.07$ & $29.83^{b} \pm 0.14$ \\
\hline C9 & $0.71^{\mathrm{a}} \pm 0.01$ & $81.45^{c} \pm 0.08$ & $1.48^{\mathrm{a}} \pm 0.01$ & $72.64^{c} \pm 0.07$ & $5.88^{\mathrm{d}} \pm 0.06$ & $21.48^{\mathrm{a}} \pm 0.09$ & $30.08^{b} \pm 0.17$ \\
\hline
\end{tabular}

Differences between average values marked with the same Arabic letters $(\mathrm{a}-\mathrm{d})$ are not statistically significant at the level of $p \leq 0.05$ according to the Duncan test.

The content of ash in the control sample (1.5\%) was slightly lower than with the apple branches, whereas in biochars produced from cherry branches, the value reached a level of $5.88 \%$. The highest ash contents were identified in the materials subjected to pyrolysis at $450{ }^{\circ} \mathrm{C}$ for $15 \mathrm{~min}$ and at $500{ }^{\circ} \mathrm{C}$ for a duration of 5, 10, and $15 \mathrm{~min}$. The content of volatile substances in the biochars produced from cherry branches decreased over three-fold compared to the materials not subjected to thermal processing. The lowest content of volatile substances, at a level of $21.28 \%$, was identified in the case of biochar produced at a temperature of $500{ }^{\circ} \mathrm{C}$ with a residence time of $15 \mathrm{~min}$.

By subjecting cherry branch biomass to pyrolysis, it was possible to significantly increase the calorific value of the products, in the range $27.70-30.08 \mathrm{MJ} \mathrm{kg}^{-1}$. However, the findings show no statistically significant effects of the varied parameters of the process, i.e., residence time and temperature, on the calorific value of the biochars.

The content of nitrogen in pear branch biomass was $0.39 \%$, whereas the share of this element in the biochars was in the range of $0.47-0.93 \%$ (Table 5). By subjecting pear branch biomass to pyrolysis, it was possible to increase the content of total carbon from $37.91 \%$ to values in the range of $65.02-72.66 \%$. The fixed carbon content of the tested materials was in the range of $13.7-71.34 \%$. An opposite trend was identified in the case of hydrogen content, which decreased with higher temperatures and a longer duration of the process.

Table 5. Contents of total nitrogen, total carbon, hydrogen, fixed carbon, ash, volatile substances, and calorific value in non-processed biomass of pear branches and in the biochars produced.

\begin{tabular}{|c|c|c|c|c|c|c|c|}
\hline & Nitrogen & Carbon & Hydrogen & Fixed Carbon & Ash & Volatile Substances & Calorific Value \\
\hline & \multicolumn{6}{|c|}{$\%$} & MJ kg-1 \\
\hline P0 & $0.39^{\mathrm{a}} \pm 0.04$ & $37.91^{\mathrm{a}} \pm 0.10$ & $5.30^{d} \pm 0.02$ & $13.7^{\mathrm{a}} \pm 0.07$ & $4.54^{\mathrm{a}} \pm 0.08$ & $72.76^{\mathrm{d}} \pm 0.08$ & $16.67^{\mathrm{a}} \pm 0.03$ \\
\hline P1 & $0.93^{f} \pm 0.20$ & $65.02^{b} \pm 0.20$ & $3.59^{c} \pm 0.04$ & $64.05^{b} \pm 0.06$ & $7.17^{b} \pm 0.06$ & $28.78^{c} \pm 0.12$ & $25.42^{b} \pm 0.07$ \\
\hline P2 & $0.91^{\mathrm{f}} \pm 0.05$ & $67.82^{b} \pm 0.11$ & $3.51^{\mathrm{c}} \pm 0.02$ & $64.28^{b} \pm 0.05$ & $7.41^{b} \pm 0.05$ & $28.31^{\mathrm{c}} \pm 0.06$ & $26.09^{b} \pm 0.06$ \\
\hline P3 & $0.83^{\mathrm{e}} \pm 0.06$ & $68.51^{b} \pm 0.14$ & $3.44^{c} \pm 0.02$ & $64.96^{b} \pm 0.09$ & $7.92^{b c} \pm 0.05$ & $27.12^{b c} \pm 0.12$ & $26.26^{b} \pm 0.08$ \\
\hline P4 & $0.83^{\mathrm{e}} \pm 0.01$ & $67.46^{b} \pm 0.10$ & $2.93^{b} \pm 0.02$ & $65.3^{b} \pm 0.09$ & $8.35^{b c} \pm 0.07$ & $26.2^{b c} \pm 0.11$ & $25.98^{b} \pm 0.11$ \\
\hline P5 & $0.85^{\mathrm{e}} \pm 0.01$ & $69.19^{b c} \pm 0.07$ & $2.92^{\mathrm{b}} \pm 0.01$ & $66.73^{b} \pm 0.03$ & $8.76^{c} \pm 0.03$ & $24.51^{b c} \pm 0.03$ & $26.95^{b} \pm 0.09$ \\
\hline P6 & $0.75^{\mathrm{d}} \pm 0.03$ & $70.52^{b c} \pm 0.08$ & $2.81^{\mathrm{ab}} \pm 0.01$ & $68.28^{b} \pm 0.07$ & $9.16^{c} \pm 0.06$ & $22.56^{\mathrm{bc}} \pm 0.09$ & $27.26^{b} \pm 0.03$ \\
\hline P7 & $0.55^{c} \pm 0.01$ & $68.19^{b} \pm 0.07$ & $2.58^{\mathrm{a}} \pm 0.02$ & $69.76^{b} \pm 0.05$ & $8.71^{\mathrm{c}} \pm 0.04$ & $21.53^{\mathrm{a}} \pm 0.06$ & $27.46^{b} \pm 0.11$ \\
\hline P8 & $0.56^{c} \pm 0.01$ & $72.22^{c} \pm 0.03$ & $2.56^{\mathrm{a}} \pm 0.02$ & $70.83^{b} \pm 0.03$ & $8.81^{c} \pm 0.01$ & $20.36^{\mathrm{a}} \pm 0.04$ & $27.88^{b} \pm 0.11$ \\
\hline P9 & $0.47^{\mathrm{b}} \pm 0.01$ & $72.66^{c} \pm 0.11$ & $2.35^{\mathrm{a}} \pm 0.01$ & $71.34^{c} \pm 0.08$ & $9.41^{c} \pm 0.07$ & $19.25^{\mathrm{a}} \pm 0.1$ & $28.31^{b} \pm 0.07$ \\
\hline
\end{tabular}

Differences between average values marked with the same Arabic letters (a-f) are not statistically significant at the level of $p \leq 0.05$ according to the Duncan test. 
The content of ash in pear branch biomass (4.54\%) was much higher than in apple and cherry branch biomass. Accordingly, the biochars produced from pear biomass had higher ash contents when compared to the biochars obtained from the latter materials, with the maximum value obtained being $9.41 \%$. The volatile contents in the control sample $(72.76 \%)$ and in the biochars (19.25-28.78\%) were slightly higher than in the materials discussed earlier.

Pear branch biomass was found to have the lowest calorific value (16.67 MJ kg ${ }^{-1}$ ) when compared to the other investigated materials. The application of the pyrolysis process made it possible to increase the calorific value of the biochar to the maximum value $28.30 \mathrm{MJ} \mathrm{kg}^{-1}$. No statistically significant differences related to this parameter were identified between the specific products of pyrolysis.

Table 6 presents measurements of maximum explosion pressure $P_{\max }$, maximum rate of pressure rise $(d p / d t)_{\max }$, and lower explosion limits for dust from apple, cherry, and pear branches as well as the biochars produced. The tests showed similar trends in the findings relating to the three types of biomass and the biochars. The mean $P_{\max }$ identified for the relevant types of biomass amounted to $7.69 \mathrm{bar}$, and this indicator increased to a maximum value of 11.15 bar in the biochars processed at a temperature of $500{ }^{\circ} \mathrm{C}$ for a duration of $15 \mathrm{~min}$. An increase in the maximum explosion pressure was positively correlated to the temperature and the duration of the pyrolysis process. A similar trend was also observed with regard to changes in the maximum rate of pressure rise. The parameter assumed the lowest values in the case of the non-processed waste biomass from fruit trees, and these tended to increase in the biochars processed at higher temperatures and with longer residence times. Compared to all of the materials investigated, the highest value of $(d p / d t)_{\max }$ amounting to 353.41 bar s $^{-1}$ was identified in the biochar produced from pear branch biomass as a result of the pyrolysis process conducted at the highest temperature and with the longest residence time. The findings also show differences in the values of the lower explosion limit measured in the dust from the biomass and from the biochars relative to the parameters in the pyrolysis process. The value of the lower explosion limit was found to decrease with higher values of the pyrolysis process parameters, i.e., $400{ }^{\circ} \mathrm{C} / 15 \mathrm{~min}$, or more for apple branch biomass, $450^{\circ} \mathrm{C} / 15 \mathrm{~min}$. or more for cherry tree biomass as well as $450{ }^{\circ} \mathrm{C} / 10 \mathrm{~min}$. or more for pear biomass. In the explosion tests, the materials reached the lower level explosion limit (LEL) at levels 500 and $750 \mathrm{~g} \mathrm{~m}^{3}$. Below the indicated values, the analyzed materials did not show any explosive properties. Materials with a higher LEL parameter are considered safer. The variability of the levels of this parameter is due to the physicochemical properties of the raw biomass and materials after thermal conversion, such as particle size and shape as well as bulk density.

Table 6. Maximum explosion pressure, maximum rate of pressure rise, and lower explosion limit for dust from apple, cherry, and pear branches and in the biochars produced.

\begin{tabular}{|c|c|c|c|}
\hline \multirow{2}{*}{ Material } & $\mathbf{P}_{\max }$ & $(d p / d t)_{\max }$ & LEL-Lower Explosion Limit \\
\hline & bar & bar $s^{-1}$ & $\mathrm{~g} \mathrm{~m}^{3}$ \\
\hline A0 & 7.70 & 279.59 & \multirow{3}{*}{750} \\
\hline A1 & 8.13 & 286.87 & \\
\hline A2 & 8.45 & 291.47 & \\
\hline A3 & 8.77 & 299.17 & \multirow{7}{*}{500} \\
\hline A4 & 9.20 & 304.20 & \\
\hline A5 & 9.84 & 317.36 & \\
\hline A6 & 9.96 & 320.06 & \\
\hline A7 & 10.25 & 324.52 & \\
\hline A8 & 10.85 & 329.11 & \\
\hline A9 & 11.04 & 332.64 & \\
\hline
\end{tabular}


Table 6. Cont.

\begin{tabular}{|c|c|c|c|}
\hline \multirow{2}{*}{ Material } & $\mathbf{P}_{\max }$ & $(d p / d t)_{\max }$ & LEL-Lower Explosion Limit \\
\hline & bar & bar s $^{-1}$ & $\mathrm{~g} \mathrm{~m}^{3}$ \\
\hline $\mathrm{CO}$ & 7.56 & 274.77 & \multirow{4}{*}{750} \\
\hline $\mathrm{C} 1$ & 7.95 & 282.05 & \\
\hline $\mathrm{C} 2$ & 8.26 & 286.44 & \\
\hline $\mathrm{C} 3$ & 8.66 & 294.58 & \\
\hline $\mathrm{C} 4$ & 9.08 & 298.77 & \multirow{6}{*}{500} \\
\hline C5 & 9.61 & 312.43 & \\
\hline C6 & 9.65 & 310.20 & \\
\hline $\mathrm{C} 7$ & 9.93 & 314.52 & \\
\hline $\mathrm{C} 8$ & 10.52 & 318.97 & \\
\hline C9 & 10.70 & 322.39 & \\
\hline P0 & 7.80 & 284.97 & \multirow{5}{*}{750} \\
\hline $\mathrm{P} 1$ & 8.32 & 293.48 & \\
\hline $\mathrm{P} 2$ & 8.67 & 297.09 & \\
\hline P3 & 8.91 & 305.28 & \\
\hline $\mathrm{P} 4$ & 9.43 & 309.71 & \\
\hline P5 & 10.11 & 323.65 & \multirow{5}{*}{500} \\
\hline P6 & 10.58 & 340.04 & \\
\hline P7 & 10.89 & 344.79 & \\
\hline P8 & 11.52 & 349.66 & \\
\hline P9 & 11.72 & 353.41 & \\
\hline
\end{tabular}

The value of the explosion index $K_{s t}$ max, i.e., the parameter directly enabling the classification of the dust explosion hazard, was calculated in accordance with the relevant standard [24]. The values of the identified index show that both the non-processed biomass from fruit tree branches as well as the biochars represent a Class 1 risk of dust explosion (St1) - reflecting a low explosion hazard. The explosion index for apple, cherry, and pear branch biomass was 75.77, 74.46, 77.23 bar s$^{-1}$, respectively. An increase in the value of this parameter corresponded to an increase in the temperature and the duration of the pyrolysis process applied to the plant biomass. In each case the biochars produced at $500{ }^{\circ} \mathrm{C} / 15 \mathrm{~min}$, they were found to have the highest values of the index. Compared to all of the materials investigated, biochar made from pear branches had the highest explosion index of 95.77 bar s$^{-1}$ (Figure 2). 


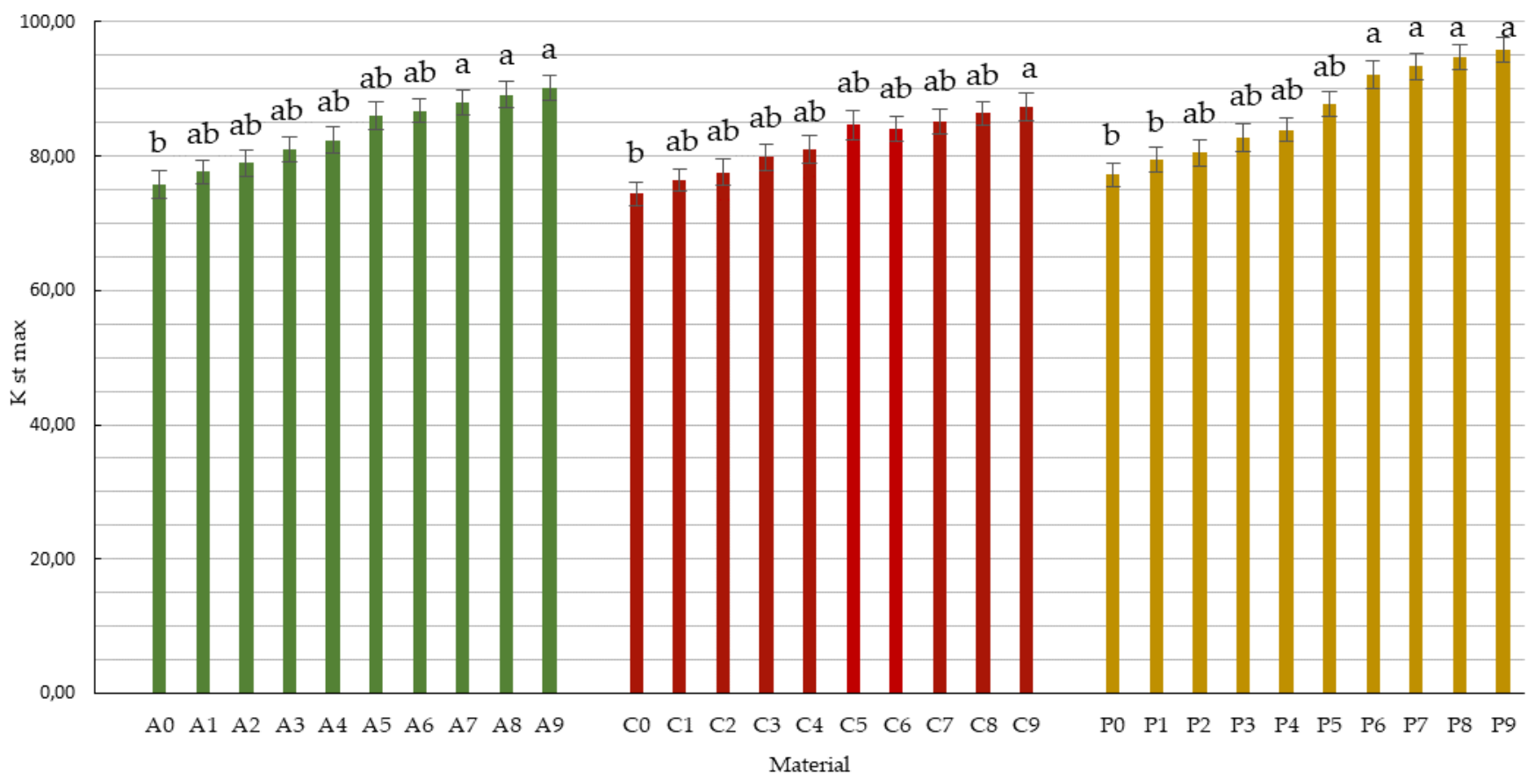

Figure 2. Changes in dust explosivity rates in samples of apple, cherry, and pear branches and in the biochars produced. Differences between average values marked with the same Arabic letters ( $a-b)$ are not statistically significant at the level of $p \leq 0.05$ according to the Duncan test.

Figure 3 presents the changes in explosion pressure relative to material and time. Similar trends in the changes of this parameter were observed in the case of all of the materials investigated, which resulted from the differences in the parameters of the pyrolysis process and from the higher temperatures in particular. The maximum explosion pressure was observed $200 \mathrm{~ms}$ after the initiation of the explosion in the case of the materials from apple, cherry, and pear branches not subjected to thermal processing (Figure 3). The maximum values of this parameter relating to the other materials (biochars) were identified at the same timepoints during the analysis. 


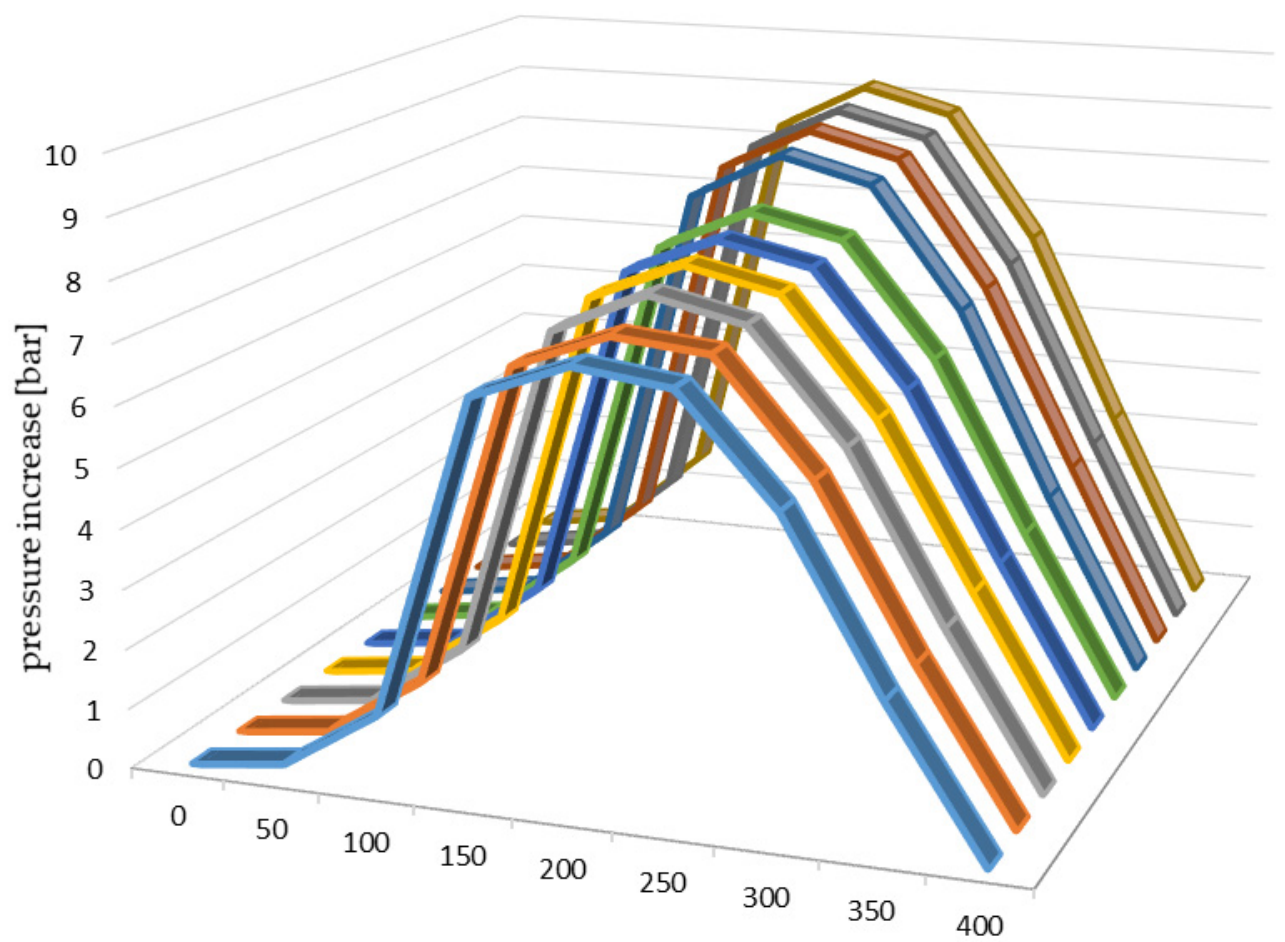

time [ms]

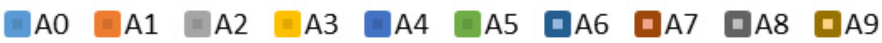

(a)

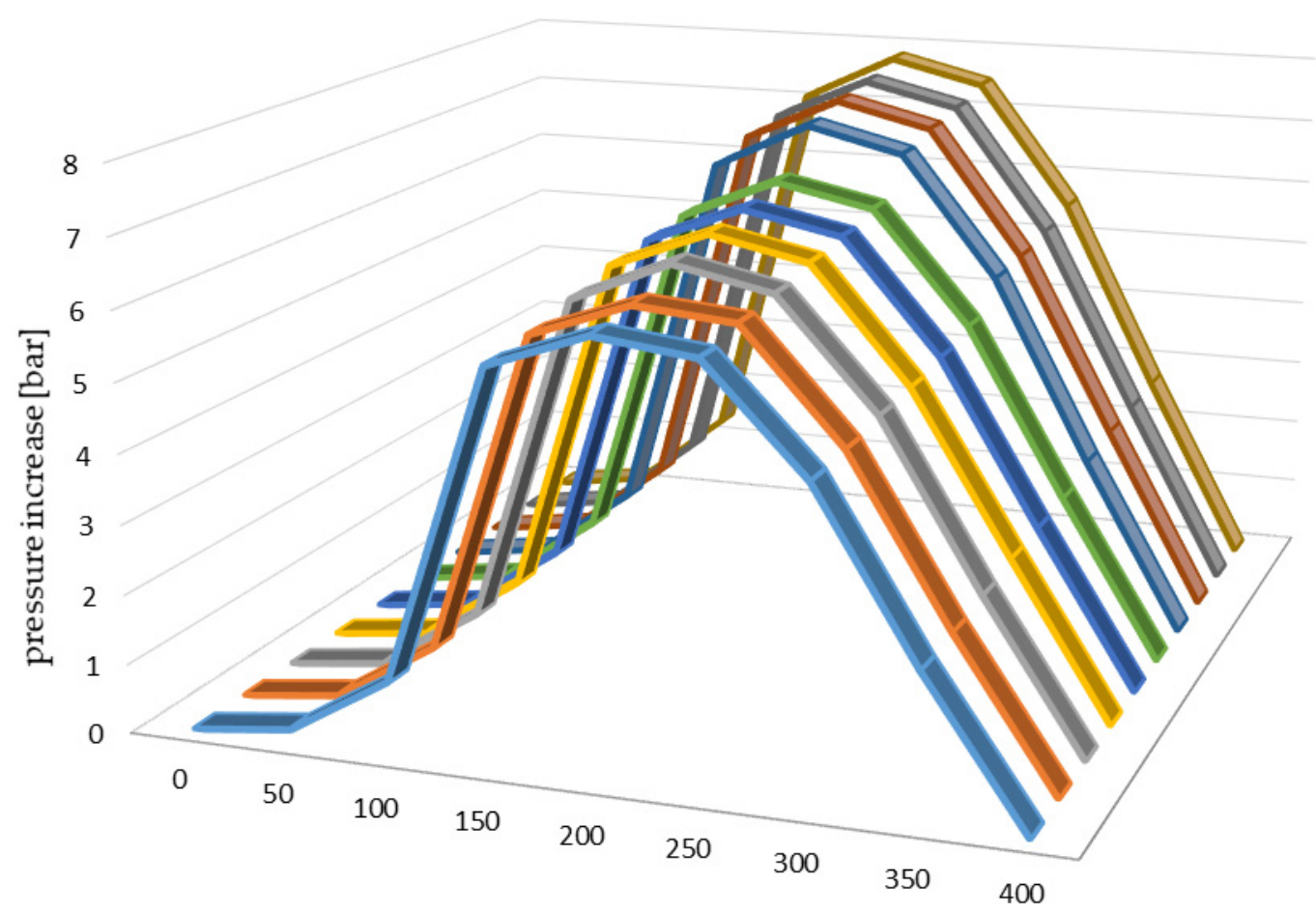

time [ms]

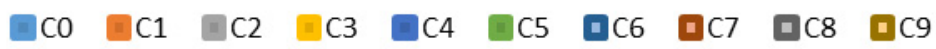

(b)

Figure 3. Cont. 


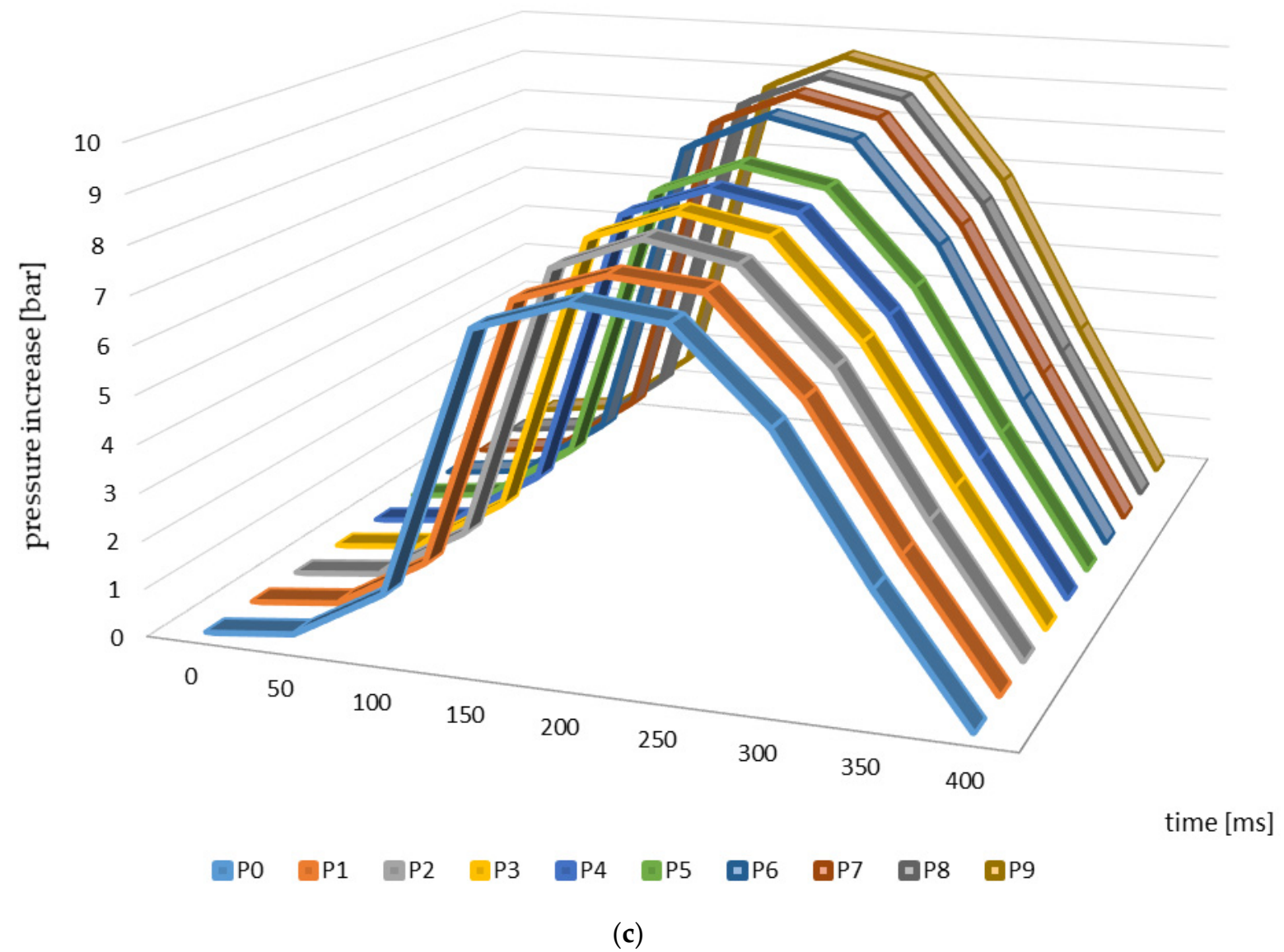

Figure 3. Explosion pressure curves identified for the branches and biochar samples ((a)—apple, (b)—cherry, (c)—pear).

\section{Discussion}

There are many processes that make it possible to improve the properties of various materials for energy-related purposes. These include the pyrolysis process, which is mainly designed to increase the calorific value of the materials subjected to processing, with this parameter being one of the key factors determining the fuel efficiency.

In the present study, the pyrolysis process was conducted at a temperature of 400, 450, or $500{ }^{\circ} \mathrm{C}$ with a residence time of 5,10 , or $15 \mathrm{~min}$, and the research material was waste biomass from orchards, i.e., apple, cherry, and pear branches. In each case, the biochars, or the products of pyrolysis conducted at various temperatures and for various lengths of time, differed from the control sample (non-processed branch biomass) in their per cent contents of basic elements. The findings show that the contents of total carbon increased with higher temperature and longer pyrolysis process duration. The highest contents of total carbon were found in the most heavily processed materials $\left(500^{\circ} \mathrm{C} / 15 \mathrm{~min}\right)$. In the case of pear and apple, the value was $72.66 \%$ and $73.63 \%$, respectively, while the highest total carbon content of $81.45 \%$ was found in the biochar from cherry branches. Similar relationships were reported by Bajcar et al. (2018), who applied thermal processing to rapeseed straw, wheat straw, and energy willow (at temperatures of 220,260 , and $300{ }^{\circ} \mathrm{C}$ for a duration of 60,75 , and $90 \mathrm{~min}$ ). The study demonstrated that higher temperatures were associated with an increase in the contents of total carbon [36]. The structural and physicochemical properties of biochar were also investigated by Zhao et al. (2019). In this case, pyrolysis was applied to apple tree branches that had been treated at 300, 400, 500 , and $600{ }^{\circ} \mathrm{C}$. The study showed that an increase in the temperature leads to a greater per cent content of carbon and a higher content of such elements as K, P, Fe, Zn, Ca, and $\mathrm{Mg}$. These authors concluded that the pyrolysis temperature significantly affects the properties of biochar [37]. Al-Wabel et al. (2013) subjected Conocarpus waste to thermal 
processing at various temperatures $\left(200-800{ }^{\circ} \mathrm{C}\right)$ and reported that an increase in the pyrolysis temperature coincided with higher contents of total carbon [38]. In one of the studies conducted by Pehlivan et al. (2017), cherry pulp was subjected to pyrolysis at the temperatures of $400,500,550,600$, and $700{ }^{\circ} \mathrm{C}$ and where three different heating rates were applied (increase of 10,100 , and $200{ }^{\circ} \mathrm{C} / \mathrm{min}$ ). The authors concluded that at the highest temperatures, the biochar, which had formed during the primary pyrolysis, underwent secondary reactions, and the percentage of liquid and gaseous products increased at the expense of carbon. The use of a lower temperature led to the increased efficiency of the charring process. At excessive temperatures, the energy provided to the biomass promoted the release of volatile substances [39]. In a study by Jindo et al. (2014), pyrolysis was applied to agricultural residues and organic wastes, such as rice husk and straw and wood chips from apple and oak trees. The process was conducted at 400, 500, 600, 700, and $800{ }^{\circ} \mathrm{C}$ and was intended to optimise the physicochemical properties of the biochars, which were to be used as a soil amendment. The biochar obtained from oak and apple wood chips had a higher content of carbon [40]. Those findings confirm that the properties of the input material subjected to pyrolysis are important for the quality of the produced biochar. Unique physical properties were acquired by the biochar produced from rice residues because of the silica content. Sànchez et al. (2009) assessed the properties of biochar from waste biomass and reported an over twofold increase in the total carbon content from a mean of $31 \%$ in the unprocessed biomass to a mean of $68 \%$ in the pyrolysis products [41]. Gherghe et al. (2009) observed an increased content of carbon in the biochar produced via pyrolysis from cherry sawdust compared to the non-processed sample. The authors identified a positive correlation between temperature increase and the carbon content in the pyrolysates [42].

The findings show a decrease in nitrogen content coinciding with an increase in the temperature and residence time. The highest contents of total nitrogen were identified in the least transformed biochars (at $400{ }^{\circ} \mathrm{C} / 5 \mathrm{~min}$ ), and the lowest value was identified in the unprocessed biomass. Conversely, Al-Wabel et al. (2013) observed an increase in the nitrogen content corresponding to an increase in the process temperature [38].

The present study also shows that the amounts of ash and volatile substances in the products were strongly related to the parameters of the pyrolysis process. A study conducted by Bajcar et al. (2018) demonstrated that an increase in the process temperature led to a higher ash content and to a decrease in the weight of the material [36]. The torrefaction process was also investigated by Babinszki et al. (2020), who in this specific study, focused on the processing of water fern (azolla), a potential source of biomass for energy-related purposes. The process was conducted at 260,280 , and $300{ }^{\circ} \mathrm{C}$; however, the ash content in the azolla biomass (8.7\%) did not significantly change as a result of the treatment compared to the input material [43]. The present study also assessed the content of volatile substances in relation to the temperature and duration of the pyrolysis process. The findings show a decrease in volatile content with increasing pyrolysis temperature and the longer residence of the material in the reactor, which is consistent with the results reported by Bajcar et al. (2018) in a study assessing the effects of the torrefaction process applied to willow and agricultural residues [36]. A study by Zhao et al. (2019) also reported that the contents of volatile substances decrease with a higher temperature applied in the process [37]. Pehlivan et al. (2017) concluded that volatile substances are released in the form of gas, which is reflected by a decreased volume of the produced biochar [39]. Similar conclusions were reached by Choi et al. (2012), who investigated the effects of fast pyrolysis applied to lignocellulosic biomass. They observed that an increase in the rate at which the biomass is fed into the reactor leads to a higher yield of the liquid fraction. It was also observed that a maximum temperature of approximately $500{ }^{\circ} \mathrm{C}$ can be applied in pyrolysis for bio-oil production; if that is exceeded, the content of the gaseous fraction increases significantly [44]. Sànchez et al. (2009) reported that the ash content in the raw biomass of the materials taken into account in the study was in the range of $7.3-8.3 \%$, and the volatile contents were $74.5-78.7 \%$, whereas in the processed biomass, the ash content increased to 
21.8-28.9\%, and volatile content decreased to 13.4-13.6\% [41]. Sukiran et al. (2011) assessed the pyrolysates obtained from oil palm residues and reported an ash content of $3.1 \%$ and a volatile content of $81.9 \%$ [45]. Gheorghe et al. (2009) reported that at temperatures of 450, 600 and $800{ }^{\circ} \mathrm{C}$, the contents of volatile substances amounted to $22.21,24.41$, and $18.94 \%$, respectively. A higher pyrolysis temperature led to a decrease in the moisture and the volatile fraction content and led to an increase in the ash content [42]. Al-Wabel et al. (2013) reported a tendency for the oxygen, hydrogen and sulphur contents to decrease [38].

The present study showed the highest hydrogen contents in the non-processed samples, which resulted from the greater moisture content in the raw materials. Zhao et al. (2019) observed that the application of pyrolysis leads to a decrease in the contents of oxygen and hydrogen and affects the oxygen to carbon and the hydrogen to carbon ratios [37]. Gheorghe et al. (2009) reported that a process temperature of $450{ }^{\circ} \mathrm{C}$ leads to $7.24 \%$ moisture content in the biochar, compared to $6.34 \%$ at a temperature of $600{ }^{\circ} \mathrm{C}$ and $6.24 \%$ at a temperature of $800{ }^{\circ} \mathrm{C}$ [42].

The findings reported in the present study show that pyrolysis led to an increase in the calorific value of the materials, on average by $62 \%$, compared to the non-processed samples. The highest calorific value was achieved at a temperature of $500{ }^{\circ} \mathrm{C}$ and a residence time of $15 \mathrm{~min}$; however, an increase in both the temperature and the duration of the process did not significantly affect the value. A study conducted by Bajcar et al. (2018) demonstrated similar relationships, i.e., the calorific value of the materials increased with higher temperature [36]. However, as pointed out by Choi et al. (2012), increasing the pyrolysis temperature to levels above a characteristic threshold value determined for a given material does not improve the effectiveness of biochar production [44]. A study by Sànchez et al. (2009) showed a mean calorific value of $23.4 \mathrm{MJ} \mathrm{kg} \mathrm{kg}^{-1}$ in the biochar produced from rapeseed, compared to $20.5 \mathrm{MJ} \mathrm{kg}^{-1}$ in the biochar produced from sunflower, and the related values in the respective non-processed materials were 15.3 and $15.7 \mathrm{MJ} \mathrm{kg}^{-1}$ [41]. Sukiran et al. (2011) reported a mean calorific value of $17.1 \mathrm{MJ} \mathrm{kg}^{-1}$ in the biochars produced from oil palm residues [45]. A relationship between the calorific value and the process temperature was also demonstrated by Sarkar and Wang (2020) in a study assessing the quality of the biochars produced from coconut shell. An increase in the process temperature from 400 to $800{ }^{\circ} \mathrm{C}$ led to an increase in the calorific value from 28.1 to $30.6 \mathrm{MJ} \mathrm{kg}^{-1}$ [46].

The present study also shows that the maximum dust explosion pressure is related to the temperature and duration of the pyrolysis process applied to the biomass. The maximum mean increase in the value of this parameter in the biochars was $45 \%$, relative to the control sample. This relationship is associated with changes in the composition and physical structure of the biochars produced in the pyrolysis process compared to those observed in the raw biomass. Pyrolysis leads to higher carbon concentrations and volatile contents and results in the increased brittleness of the thermally processed products. A similar relationship was reported by Bajcar et al. (2020), who assessed the dust explosivity in the raw biomass of wheat straw and energy willow and in products of the torrefaction process applied to those materials. The authors observed that Pmax increased by a maximum of $28 \%$ with a higher torrefaction process temperature [47]. Półka (2020) reported a maximum explosion pressure for coke dust amounting to 6.84 bar. Similar values in the ranges of 5.7-7.7 and 6.0-7.0, have been proposed with regard to coal dust and soot and wood dust, respectively [48].

Analysis of the maximum rate of pressure rise showed the lowest values in the case of raw biomass and an increase in the materials subjected to thermal processing. The highest value of 353.41 bar s $^{-1}$, recorded in the case of biochar produced from pear branches, was $24 \%$ higher than the related value measured in the case of the control sample (nonprocessed biomass). These differences are not significant, and they do not lead to the reclassification of the dust, but there is a visible trend in the changes of these values. According to the related literature, the differences between raw and pyrolysed biomass are primarily linked to the varied emissivity of these materials, which are related to the 
mechanisms of heat transfer [49-51]. As Kuai et al. (2011) have pointed out, the value of the maximum rate of pressure rise in the case of coal dust is related to the calorific value of the material. The authors argue that an increase in the calorific value of coal dust leads directly to an increase in the value of $(d p / d t)_{\max }$ [52]. The same relationship was shown in the present study.

The analyses conducted in this study suggest that an increase in the lower explosion limit may be linked to high contents of dust in non-processed biomass and in the pyrolysates produced at lower process temperatures. An increase of the pyrolysis process temperature coincided with a 33.3\% decrease in LEL in all of the types of biomass investigated, with the most dynamic changes occurring in the samples of pear branch biomass. According to the related literature, the varied levels of this factor may be associated with various physicochemical properties identified in biomass samples not subjected to thermal processing and in pyrolysates, e.g., bulk density, as well as size and shape of particles [53-55].

The tests assessing the explosion index $K_{s t}$ max showed that non-processed fruit tree biomass and the biochars produced from this material present a low risk of explosion. The value of this parameter identified in all the materials was in the range of 74.46-95.77 bar s$^{-1}$. Similar results were reported by Półka (2020), who assessed the flammability and explosivity of coke dust. The author assumed the material presented a class 1 explosion hazard, and she reported a value of $K_{s t} \max$ amounting to $64.2 \mathrm{bar} \mathrm{s}^{-1}$. A review of the related literature shows that the values of explosion index $K_{s t} \max$ for materials such as coal, soot, wood dust, aluminium, and zinc are 85, 14-22, 104, 155-550, and 25 bar s $^{-1}$, respectively [48]. Furthermore, according to researchers, this parameter is extremely important since it can be directly applied to classify specific materials, to select the guidelines for production, and to secure the processes against the risk of explosion. It also provides the basis for developing solutions and for designing preventive measures and safety systems $[17,22]$.

\section{Conclusions}

Biomass, which is a flammable material, has effectively been used in various energy systems worldwide for many years. Numerous studies conducted so far have focused on the physicochemical properties of various types of biomass and the fuels produced through the thermochemical processing of these materials. Therefore, it seems that the research findings related to raw biomass are extensive and are described in detail, whereas the products of biomass conversion often lack complete characteristics, e.g., related to the safety of their processing.

Bearing in mind the principles of sustainable development used in energy generation systems, environmental protection, or agriculture, the need for novel materials and processing methods is constantly growing. As an example, the research relating to this topic focuses on the processing of waste and on the optimisation of the methods enabling the production of high-energy fuels from these types of materials.

The article presents the results of a study assessing waste biomass from fruit trees and the biochars produced from this type of material from the viewpoint of their energy properties and processing safety. The findings show an average increase in the calorific value of $62.24 \%$ in the case of biochar obtained from fruit tree branches in relation to non-processed biomass. The mean calorific values of the biochars produced from apple, cherry, and pear branches amounted to 27.90, 28.75, and 26.84 $\mathrm{MJ} \mathrm{kg}^{-1}$, respectively. By applying higher temperatures and a longer residence time in the pyrolysis process, it was possible to obtain high contents of total carbon. Increasing the above thermal processing parameters applied to the biomass resulted in higher contents of ash and lower contents of volatile substances, nitrogen, and hydrogen in the $b$ produced biochars. Analysis of the results showed that there was an increase in the value of the explosion index $K_{s t} \max$ from 75.77 in the case of apple branches to 77.74-90.15 bar s $^{-1}$ in the case of the biochars obtained from the same material. A similar trend was observed in the changes of this 
parameter related to cherry and pear branches-the relevant values changed from 74.46 and 77.23 to $76.44-87.37$ and $79.53-95.77$ bar s $^{-1}$, respectively.

In this work, the authors presented the energy properties, explosion hazards, and methods of preparing samples typical for small installations, often home solutions, which do not have an extensive technological line. Additionally, such materials are usually stored for a long time after harvest in order to reduce the water content. Additionally, the scientific literature lacks information on wastes orchard biomass materials that could be main element of substrates in small installations.

The results of the present study suggest that waste biomass from orchards, and more specifically, cherry, pear, and apple branches, may be effectively utilised as a resource in the production of high-energy solid fuels. Furthermore, this study highlights the usefulness of pyrolysis as a thermal method enabling biomass conversion. Biochars produced in this way have good energy parameters and do not present explosion risks. It seems necessary to continue research exploring these and other similar materials and to investigate the most effective conditions for conducting thermal processing.

Author Contributions: Conceptualisation, B.S.; methodology, B.S., A.S., G.Z. and M.B.; formal analysis, B.S. and A.S.; data curation, B.S., M.B.; writing - preparation of original draft, B.S.; writingreview and editing, B.S.; supervision, C.P.; project administration, B.S. and G.Z.; funding acquisition, C.P. All authors have read and agreed to the published version of the manuscript.

Funding: The publication was funded by the Minister of Science and Higher Education under the "Regional Initiative of Excellence" programme for the years 2019-2022, Project No.026/RID/2018/19, and received PLN 9,542,500.00 of funding.

Institutional Review Board Statement: Not applicable.

Informed Consent Statement: Not applicable.

Data Availability Statement: Not applicable.

Conflicts of Interest: The authors declare no conflict of interest.

\section{References}

1. Saletnik, B.; Zaguła, G.; Bajcar, M.; Tarapatskyy, M.; Bobula, G.; Puchalski, C. Biochar as a Multifunctional Component of the Environment. Review. Appl. Sci. 2019, 9, 1139. [CrossRef]

2. Basu, P. Biomass Gasification, Pyrolysis and Torrefaction: Practical Design and Theory; Academic Press: London, UK, 2018; pp. 147-176.

3. Elkhalifa, S.; Al-Ansari, T.; Mackey, H.R.; McKay, G. Food waste to biochars through pyrolysis: A review. Resour. Conserv. Recycl. 2019, 144, 310-320. [CrossRef]

4. Lewandowski, W.M.; Ryms, M.; Meler, P. Termiczno-chemiczna piroliza do biopaliw ciekłych i gazowych, jako metoda podnoszenia sprawności konwersji energii biomasy. Naft. Gaz 2010, 8, 675-680.

5. Yin, C.Y. Prediction of higher heating values of biomass from proximate and ultimate analyses. Fuel 2011, 90, 1128-1132. [CrossRef]

6. Qian, X.; Xue, J.; Yang, Y.; Lee, S.W. Thermal Properties and Combustion-Related Problems Prediction of Agricultural Crop Residues. Energies 2021, 14, 4619. [CrossRef]

7. Idris, J.; Shirai, Y.; Anduo, Y.; Ali, A.A.M.; Othman, M.R.; Ibrahim, I.; Hassan, M.A. Improved yield and higher heating value of biochar from oil palm biomass at low retention time under self-sustained carbonization. J. Clean. Prod. 2015, 104, 475-479. [CrossRef]

8. Malińska, K. Biowegiel odpowiedzią na aktualne problemy ochrony środowiska. Inżynieria I Ochr. Sr. 2012, 15, 387-403.

9. Lehman, J.; Joseph, S. Biochar for Environmental Management: Science and Technology; Earthscan: London, UK, 2009.

10. Rahman, M.Z.; Edvinsson, T.; Kwong, P. Biochar for electrochemical applications. Curr. Opin. Green Sustain. Chem. 2020, 23, 25-30. [CrossRef]

11. Stelte, W.; Holm, J.; Sanadi, A.; Barsberg, S.; Ahrenfeldt, J.; Henriksen, U. Fuel pellets from biomass: The importance of the pelletizing pressure and its dependency on the processing conditions. Fuel 2011, 90, 3285-3290. [CrossRef]

12. Styks, J.; Wróbel, M.; Frączek, J.; Knapczyk, A. Effect of Compaction Pressure and Moisture Content on Quality Parameters of Perennial Biomass Pellets. Energies 2020, 13, 1859. [CrossRef]

13. Popovicheva, O.; Ivanov, A.; Vojtisek, M. Functional Factors of Biomass Burning Contribution to Spring Aerosol Composition in a Megacity: Combined FTIR-PCA Analyses. Atmosphere 2020, 11, 319. [CrossRef]

14. Pérez, J.; Melgar, A.; Nel Benjumea, P. Effect of operating and design parameters on the gasification/combustion process of waste biomass in fixed bed downdraft reactors: An experimental study. Fuel 2012, 96, 487-496. [CrossRef] 
15. Amyotte, P.R.; Eckhoff, R.K. Dust explosion causation, prevention and mitigation: An overview. J. Chem. Health Saf. 2010, 17, 15-28. [CrossRef]

16. Mclouth, M.E.; Paulus, H.J. Air pollution from the grain industry. J. Air Pollut. Control Assoc. 1961, 11, 313-317. [CrossRef]

17. Eckhoff, R.K. Current status and expected future trends in dust explosion research. J. Loss Prev. Process Ind. 2005, 18, 225-237. [CrossRef]

18. Abbasi, T.; Abbasi, S.A. Dust explosions-Cases, causes, consequences, and control. J. Hazard. Mater. 2007, 140, 7-44. [CrossRef]

19. Pak, S.; Jung, S.; Roh, C.; Kang, C. Case Studies for Dangerous Dust Explosions in South Korea during Recent Years. Sustainability 2019, 11, 4888. [CrossRef]

20. Amyotte, P.R. Some myths and realities about dust explosions. Process Saf. Environ. Prot. 2014, 92, 292-299. [CrossRef]

21. Amyotte, P.R. An Introduction to Dust Explosions: Understanding the Myths and Realities of Dust Explosions for a Safer Workplace, 1st ed.; Elsevier: Waltham, MA, USA, 2013; pp. 117-120.

22. Taveau, J. Secondary dust explosions: How to prevent them or mitigate their effects? Process Saf. Prog. 2012, 31, 36-50. [CrossRef]

23. Haghighi Mood, S.; Hossein Golfeshan, A.; Tabatabaei, M.; Salehi Jouzani, G.; Hassan Najafi, G.; Gholami, M.; Ardjmand, M. Lignocellulosic biomass to bioethanol, a comprehensive review with a focus on pretreatment. Renew. Sustain. Energy Rev. 2013, 27,77-93. [CrossRef]

24. Kakitis, A.; Nulle, I. Electrostatic Biomass Mixing. Eng. Rural. Dev. 2009, 8, 247-252.

25. Dibble, C.J.; Shatova, T.A.; Jorgenson, J.L.; Stickel, J.J. Particle morphology characterization and manipulation in biomass slurries and the effect on rheological properties and enzymatic conversion. Biotechnol. Progr. 2011, 27, 1751-1759. [CrossRef]

26. EN14034, Part 2. Determination of Explosion Characteristics of Dust Clouds-Part 2: Determination of the Maximum Rate of Explosion Pressure Rise (dp/dt) Max of Dust Clouds. 2011. Available online: https:/ /infostore.saiglobal.com/en-us/Standards / EN-14034-2-2006-A1-2011-328536_SAIG_CEN_CEN_756384 (accessed on 6 July 2020).

27. British Standards Institution. Solid Biofuels_Determination of Total Carbon, Hydrogen and Nitrogen Content-Instrumental Methods; British Standards Institution: London, UK, 2011.

28. British Standards Institution. Solid Biofuels—Determination of Ash; British Standards Institution: London, UK, 2010.

29. British Standards Institution. Solid Biofuels—Determination of Volatile Substances; British Standards Institution: London, UK, 2011.

30. British Standards Institution. Solid Biofuels_Determination of Calorific Value; British Standards Institution: London, UK, 2010.

31. EN 14034, Part 1. Determination of Explosion Characteristics of Dust Clouds_Part 1: Determination of the Maximum Explosion Pressure Pmax of Dust Clouds. 2011. Available online: https://www.researchgate.net/publication/282893830_Determination_ Of_The_Maximum_Explosion_Pressure_And_The_Maximum_Rate_Of_Pressure_Rise_During_Explosion_Of_Wood_Dust_ Clouds (accessed on 6 July 2020).

32. EN 14034, Part 3. Determination of Explosion Characteristics of Dust Clouds-Part 3: Determination of the Lower Explosion Limit LEL of Dust Clouds. 2011. Available online: https:/ /infostore.saiglobal.com/en-us/standards/din-en-14034-3-2011-04-40 0553_saig_din_din_862949 (accessed on 6 July 2020).

33. Qian, X. Statistical Analysis and Evaluation of the Advanced Biomass and Natural Gas Co-Combustion Performance. Ph.D. Thesis, Morgan State University, Baltimore, MD, USA, 2019.

34. Chen, W.H.; Lin, Y.Y.; Liu, H.C.; Baroutian, S. Optimization of food waste hydrothermal liquefaction by a two-step process in association with a double analysis. Energy 2020, 199, 117438. [CrossRef]

35. Hanif, M.U.; Zwawi, M.; Capareda, S.C.; Iqbal, H.; Algarni, M.; Felemban, B.F.; Bahadar, A.; Waqas, A. Influence of Pyrolysis Temperature on Product Distribution and Characteristics of Anaerobic Sludge. Energies 2020, 13, 79. [CrossRef]

36. Bajcar, M.; Zaguła, G.; Saletnik, B.; Tarapatskyy, M.; Puchalski, C. Relationship between torrefaction parameters and physicochemical properties of torrefied products obtained from selected plant biomass. Energies 2018, 11, 2919. [CrossRef]

37. Zhao, S.-X.; Ta, N.; Wang, X.-D. Effect of temperature on the structural and physicochemical properties of biochar with apple tree branches as feedstock material. Energies 2019, 10, 1293. [CrossRef]

38. Al-Wabel, M.; Al-Omran, A.; El-Naggar, A.H.; Naddem, M.; Usman, A.R.A. Pyrolysis temperature induced changes in characteristics and chemical composition of biochar produced from conocarpus wastes. Bioresour. Technol. 2013, 131, 374-379. [CrossRef]

39. Pehlivan, E.; Özbay, N.; Yargıç, A.S.; Şahin, R.Z. Production and characterization of chars from cherry pulp via pyrolysis. J. Environ. Manag. 2017, 203, 1017-1025. [CrossRef] [PubMed]

40. Jindo, K.; Mizumoto, H.; Sewada, Y.; Sanchez-Monedero, M.A.; Sonoki, T. Physical and chemical characterizations of biochars derived from different agricultural residues. Biogeosciences 2014, 11, 6613-6662. [CrossRef]

41. Sànchez, M.E.; Lindao, E.; Margaleff, D.; Martínez, O.; Morán, A. Pyrolysis of agricultural residues from rape and sunflower: Production and characterization of biofuels and biochar soil management. J. Anal. Appl. Pyrolysis 2009, 85, 142-144. [CrossRef]

42. Gheorghe, C.; Marculescu, C.; Badea, A.; Dinca, C.; Apostol, T. Effect of pyrolysis conditions on bio-char production biomass. In Proceedings of the 3rd WSEAS International Conference on Renewable Energy Sources, Tenerife, Canary Islands, Spain, 1-3 July 2009.

43. Babinszki, B.; Jakab, E.; Sebestyén, Z.; Blazsó, M.; Berényi, B.; Kumar, J.; Krishna, B.B.; Bhaskar, T.; Czégény, Z. Comparison of hydrothermal carbonization and torrefaction of azolla biomass: Analysis of the solid products. J. Anal. Appl. Pyrolysis 2020, 149, 104844. [CrossRef] 
44. Choi, H.S.; Choi, Y.S.; Park, H.C. Fast pyrolysis characteristics of lignocellulosic biomass with varying reaction conditions. Renew. Energy 2012, 42, 131-135. [CrossRef]

45. Sukiran, M.A.; Kheang, L.S.; Baker, N.A.; May, C.Y. Production and characterization of biochar from the pyrolysis of empty fruit bunches. Am. J. Appl. Sci. 2011, 8, 984-988. [CrossRef]

46. Sarkar, J.K.; Wang, Q. Different Pyrolysis Process Conditions of South Asian Waste Coconut Shell and Characterization of Gas, Bio-Char, and Bio-Oil. Energies 2020, 13, 1970. [CrossRef]

47. Bajcar, M.; Saletnik, B.; Zaguła, G.; Puchalski, C. Analysis of the Effect of the Biomass Torrefaction Process on Selected Parameters of Dust Explosivity. Molecules 2020, 25, 3525. [CrossRef]

48. Półka, M. An Analysis of Flammability and Explosion Parameters of Coke Dust and Use of Preliminary Hazard Analysis for Qualitative Risk Assessment. Sustainability 2020, 12, 4130. [CrossRef]

49. Cashdollar, K.L. Overview of dust explosibility characteristics. J. Loss Prev. Process. Ind. 2000, 13, 183-199. [CrossRef]

50. Cordero, T.; Marquez, F.; Rodriquez-Mirasol, J.; Rodriguez, J.J. Predicting heating values of lignocellulosic and carbonaceous materials from proximate analysis. Fuel 2001, 80, 1567-1571. [CrossRef]

51. Demirbas, A. Calculation of higher heating values of biomass fuels. Fuel 1997, 76, 431-434. [CrossRef]

52. Kuai, N.; Huang, W.; Yuan, J.; Du, B.; Li, Z.; Wu, Y. Experimental investigations of coal dust-inertant mixture explosion behaviors. Procedia Eng. 2011, 26, 1337-1345. [CrossRef]

53. Kok, M.V.; Ozgur, E. Thermal analysis and kinetics of biomass samples. Fuel Process. Technol. 2013, 106, 739-743. [CrossRef]

54. Medina, C.H.; Phylaktou, H.N.; Sattar, H.; Andrews, G.E.; Gibbs, B.M. The development of an experimental method for the determination of the minimum explosible concentration of biomass powders. Biomass Bioenergy 2013, 53, 95-104. [CrossRef]

55. Ragland, K.W.; Aerts, D.J.; Baker, A.J. Properties of wood for combustion analysis. Bioresour. Technol. 1991, 37, 161-168. [CrossRef] 